\title{
ХАРАКТЕРИСТИКА НОВИХ СОРТІВ ПШЕНИЦІ ОЗИМОЇ МИРОНІВСЬКОЇ СЕЛЕКЦЇ̈ ЗА СТІЙКІСТЮ ПРОТИ СЕПТОРІОЗУ ЛИСТЯ
}

T. I. Муха, О. А. Заїма

Миронівський інститут пшениці імені В. М. Ремесла НААН

Наведено результати з вивчення стійкості нових сортів пшениці озимої миронівської селекції на штучному інфекційному фоні септоріозу листя протягом 2008-2012 рр. Показано характеристику погодних умов за роки досліджень і вплив їх на розвиток септоріозу листя. Погодні умови 2008, 2009, 2010 та 2012 років були сприятливими для розвитку даного захворювання в зоні діяльності Миронівського інституту. Ураження сортів озимої пшениці збудником Septoria tritici Rob. et Desm. сягало 40 \% в залежності від погодних умов і генотипу сорту. Високу стійкість до септоріозу листя показав сорт Оберіг Миронівський. Стійкість проти даного збудника проявили сорти Світанок Миронівський, Легенда Миронівська, Калинова, Колос Миронівщини, Економка, Ювіляр миронівський, Миронівська сторічна, Пам’яті Ремесла та інші.

Пшениця озима, сорт, стійкість до хвороб, септоріоз, погодні умови

Пшениця озима була і залишається основною продовольчою культурою в Україні. В умовах інтенсивного сільськогосподарського виробництва хвороби є складовою основних факторів, що лімітують зростання валових зборів продукції [1].

У сучасному виробництві зерна не втрачає актуальності проблема захисту посівів від хвороб. Потреба світового ринку в екологічно чистій сільськогосподарській продукції зумовлює тенденції до скорочення застосування хімічних засобів захисту рослин від патогенних організмів. Альтернативою застосуванню пестицидів $є$ вирощування стійких сортів, що дозволяє зменшити обсяги застосування пестицидів, які є небезпечними для людей, тварин та навколишнього середовища [1-3].

Серед хвороб пшениці м'якої озимої в Лісостеповій зоні України особливе місце займають плямистості листя, які з кожним роком набувають все більшого поширення, а їх різноманітність стрімко зростає. Найбільш розповсюдженим і шкодочинним збудником плямистостей пшениці $є$ септоріоз листя (Septoria tritici Rob. et Desm.).

(C) T. І. Мyха, О. А. Заїма. 2013.

ISSN 0582-5075. Селекція і насінництво. 2013. Випуск 103. 
Втрати врожаю від септоріозу листя залежать від ступеня розвитку хвороби. За ураження листя на $30 \%$, урожай знижується в середньому на $10 \%, 30-50 \%$ - на $20 \%$, від $51 \%$ до $75 \%$ - на $30 \%$, а якщо розвиток хвороби сягає понад $75 \%$ - на $40 \%$ [2, 3].

Тому на даний час в Україні нагальною проблемою є створення сортів озимої пшениці стійких до септоріозів, зокрема до септоріозу листя, збудником якого є незавершені гриби роду Septoria порядку Sphaeropsidales [4], питома частка якого у комплексі найпоширеніших хвороб пшениці озимої складає у різних регіонах України від 7 \% до $25 \%$ [1, 2]. Хвороба поширена практично в усіх зонах вирощування пшениці і $€$ яскравим прикладом прогресуючих і найбільш поширених хвороб листя [5].

Нині в селекційній роботі бракує стійких до септоріозу форм, тому робота в цьому напрямку є актуальною [6].

3 цією метою ми проводили оцінку з вивчення стійкості сортів пшениці озимої селекції Миронівського інституту на штучному інфекційному фоні збудника септоріозу листя.

Методики досліджень. На штучному інфекційному фоні септоріозу листя з використанням найбільш агресивних і шкодочинних ізолятів цього збудника впродовж 2008 - 2012 рр. вивчали нові перспективні сорти селекції МІП: Калинова, Колос Миронівщини, Економка, Ювіляр миронівський, Миронівська сторічна, Оберіг Миронівський, Світанок Миронівський, Легенда Миронівська, Пам'яті Ремесла, Мирлєна, Золотоколоса, Мадярка, Сніжана та інші. Ці сорти створено методом внутрішньовидової гібридизації з використанням зразків світової колекції і джерел стійкості, створених у відділі захисту рослин з подальшим добором генотипів, стійких проти ураження збудниками хвороб при використанні штучного інфекційного фону патогенів.

Як стандарти використовували сорти: Подолянка - національний стандарт; Донський напівкарлик - стандарт сприйнятливості.

Досліди з вивчення селекційного матеріалу закладали за схемами системи державного сортовипробування сільськогосподарських культур [7]. Для створення штучного інфекційного фону септоріозу листя використовували загальноприйняті методики [8-9].

Стійкість рослин проти збудника Septoria tritici Rob. et. Desm. оцінювали в динаміці. Основною вважали оцінку в період максимального розвитку хвороби - молочно-воскової стиглості [10-11].

Важливими чинниками, що визначають можливість виникнення хвороби та іiі розвиток $є$ умови навколишнього середовища, зокрема температура та вологість повітря.

Тому для визначення дії абіотичних факторів, зокрема погодних умов (кількості опадів і температури), на розвиток хвороб застосовували гідротермічний коефіцієнт - ГТК [12].

Результати досліджень. Погодні умови 2008, 2009, 2010 років сприяли розвитку септоріозу листя. Ураження сортів знаходилось в межах 
8-15 \%. Найменший відсоток ураження (1-10 \%) відмічено на сортах Колос Миронівщини, Економка, Миронівська сторічна, Золотоколоса, Мадярка, Сніжана, Оберіг Миронівський, тоді, як сорт-стандарт Подолянка уражувався на рівні $20-25 \%$, а сприйнятливий стандарт - 30-40\%. Гідротермічні коефіцієнти в ці роки становили 1,4; 1,3; 1,1 відповідно.

У 2011 році погодні умови були вкрай несприятливими для розвитку листкових хвороб. У I - II декадах червня зволоження було недостатнім (ГТК - 0,97). У цей період було відмічено лише незначний прояв хвороби. Незважаючи на те, що в третій декаді червня випали дощі (ГТК - 2,13), на розвиток листкових хвороб, у тому числі і септоріозу листя, вони не вплинули, тому що листя на рослинах уже майже засохло. Ураження рослин нових сортів пшениці озимої селекції МІП не перевищувало $1 \%$, сорту стандарту Подолянка -8 \%, а сприйнятливого стандарту - 10 \% (табл. 1).

Таблиця 1

Ураженість сортів озимої пшениці селекції МІП септоріозом листя, 2008-2012 pp.

\begin{tabular}{|l|c|c|c|c|c|c|c|}
\hline \multirow{2}{*}{ Сорт } & \multicolumn{5}{|c|}{ Ураженість септоріозом листя \% } & Бал \\
\cline { 2 - 7 } & 2008 & 2009 & 2010 & 2011 & 2012 & $\begin{array}{c}\text { серед- } \\
\text { стій- } \\
\text { кості }\end{array}$ \\
\hline $\begin{array}{l}\text { Донський напівкарлик - } \\
\text { ст. сприйнятливості }\end{array}$ & 40,0 & 30,0 & 30,0 & 10,0 & 35,0 & 29,0 & 4 \\
\hline Подолянка - нац. ст. & 20,0 & 20,0 & 25,0 & 8,0 & 20,0 & 22,6 & 5 \\
\hline Волошкова & 8,0 & 8,0 & 10,0 & 1,0 & 10,0 & 7,4 & 7 \\
\hline Калинова & 8,0 & 10,0 & 10,0 & 1,0 & 10,0 & 8,8 & 7 \\
\hline Колос Миронівщини & 8,0 & 8,0 & 8,0 & 1,0 & 8,0 & 6,6 & 7 \\
\hline Економка & 8,0 & 8,0 & 10,0 & 0 & 10,0 & 7,2 & 7 \\
\hline Ювіляр миронівський & 6,0 & 10,0 & 15,0 & 0 & 5,0 & 7,2 & 7 \\
\hline Миронівська сторічна & 8,0 & 8,0 & 10,0 & 1,0 & 10,0 & 6,2 & 7 \\
\hline Пам'яті Ремесла & 8,0 & 8,0 & 15,0 & 0 & 10,0 & 8,2 & 7 \\
\hline Золотоколоса & 8,0 & 8,0 & 10,0 & 0 & 10,0 & 7,2 & 7 \\
\hline Мирлсна & 8,0 & 8,0 & 15,0 & 1,0 & 10,0 & 8,4 & 7 \\
\hline Монотип & 8,0 & 15,0 & 10,0 & 1,0 & 15,0 & 9,8 & 7 \\
\hline Мадярка & 8,0 & 10,0 & 10,0 & 1,0 & 10,0 & 7,8 & 7 \\
\hline Сніжана & 10,0 & 10,0 & 8,0 & 1,0 & 10,0 & 7,8 & 7 \\
\hline Оберіг Миронівський & 8,0 & 5,0 & 8,0 & 1,0 & 8,0 & 6,0 & $7-8$ \\
\hline Світанок Миронівський & 15,0 & 15,0 & 10,0 & 0 & 10,0 & 10,0 & 7 \\
\hline Легенда Миронівська & 15,0 & 10,0 & 15,0 & 0 & 10,0 & 10,0 & 7 \\
\hline
\end{tabular}

У 2012 році склалися сприятливі погодні умови для розвитку листкових хвороб озимої пшениці. Квітень-травень-червень характеризувались як період з надзвичайно жаркою погодою і опадами (рис. 1, 2). 


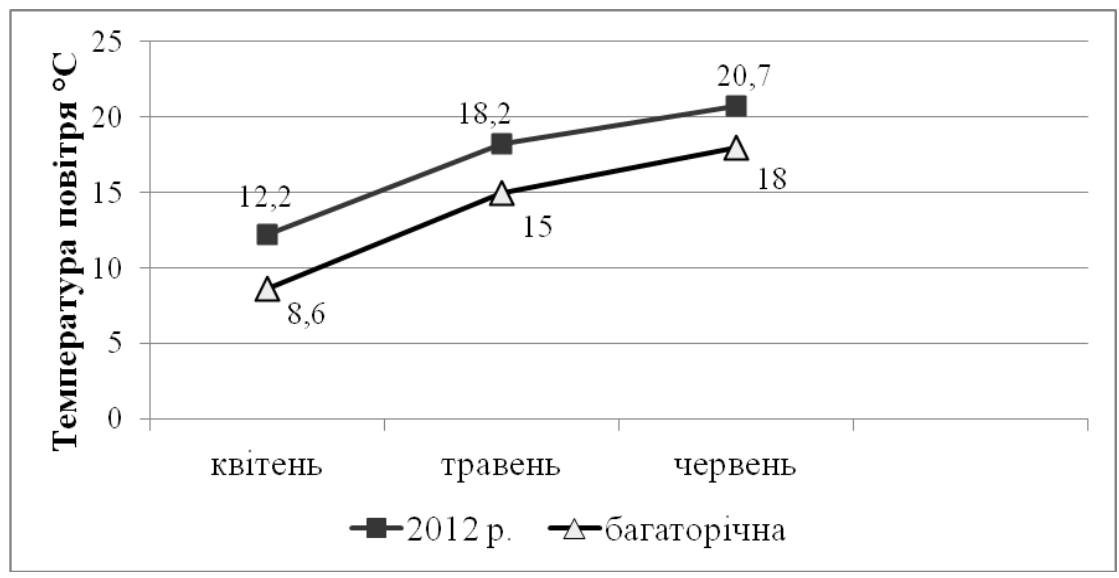

Рис. 1. Температура повітря за квітень-червень відносно до багаторічної температури, 2012 p.

Протягом всього вегетаційного періоду пшениці озимої спостерігався підвищений температурний режим. Фактична температура повітря перевищувала, як щоденну норму, так і щомісячну від $+1,4{ }^{\circ} \mathrm{C}$ у березні до $+3,6^{\circ} \mathrm{C}$ у квітні.

У квітні максимальна температура повітря сягала $+30,4{ }^{\circ} \mathrm{C}$. ГТК 3 квітня по червень становив 1,3, що свідчить про достатнє зволоження для розвитку листкових хвороб. У квітні був підвищений температурний режим 3 надмірною кількістю опадів (191% від норми).

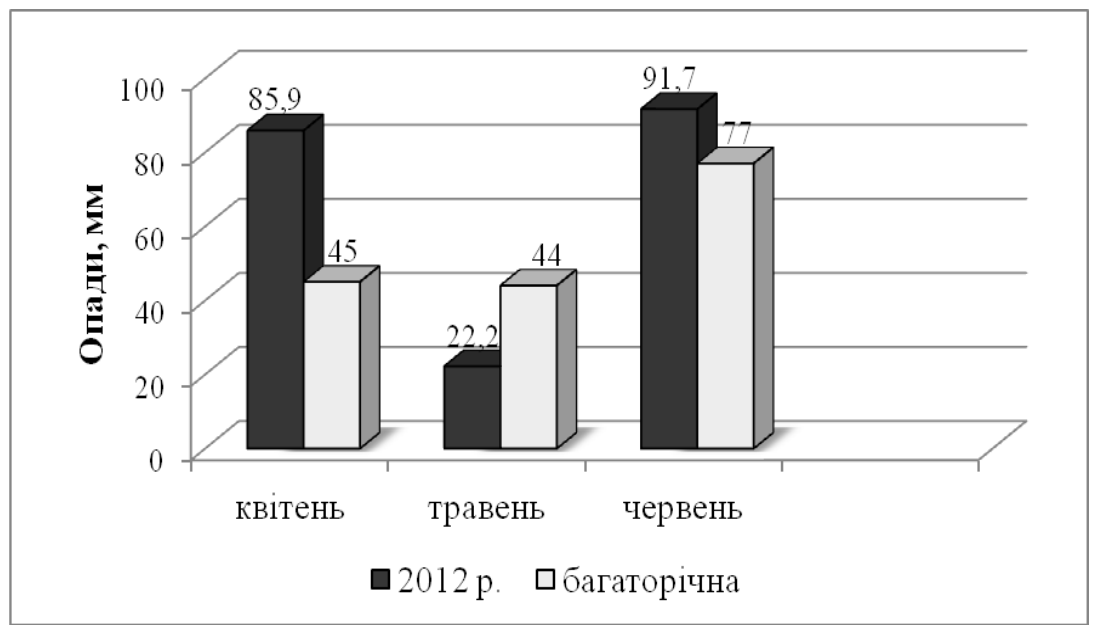

Рис. 2. Кількість опадів за квітень-червень відносно до середньо багаторічного показника, $2012 \mathrm{p}$. 
Травень характеризувався збереженням підвищеного температурного режиму на $3,2^{\circ} \mathrm{C}$ з невеликою кількістю опадів, червень - подальшим збереженням підвищеного температурного режиму на $2,7{ }^{\circ} \mathrm{C}$ з перебігом посухи і дощів, що сприяло наростанню та розвитку хвороб листя, в тому числі і Septoria tritici.

Протягом п'яти років ураження сортів пшениці озимої було різним і варіювало від $0 \%$ до $15 \%$, залежно від погодних умов вегетаційного року. Ураження сприйнятливого стандарту в середньому за п’ять років становило 29,0 \% (див. табл. 1).

Ураження досліджуваних сортів на штучному інфекційному фоні септоріозу листя в польових інфекційних розсадниках відділу захисту рослин становило 6 - $10 \%$, за ураження рослин сорту Подолянка на рівні 22,6 \%, а сприйнятливого стандарту $-29,0 \%$.

Високостійким до Septoria tritici Rob. et Desm. був сорт Оберіг Миронівський (бал 7 - 8).

Стійкість проти даного захворювання на рівні 7 балів проявили сорти Калинова, Колос Миронівщини, Економка, Ювіляр миронівський, Миронівська сторічна, Пам’яті Ремесла, Мирлєна, Золотоколоса, Мадярка, Сніжана.

Висновки. Встановлено, що сприятливі умови для розвитку септоріозу листя склалися в 2008, 2009, 2010 і 2012 рр., коли ГТК з квітня по червень становив 1,$4 ; 1,3 ; 1,1 ; 1,3$ відповідно за роками, що свідчить про достатне зволоження для розвитку септоріозу листя.

За стійкістю на штучному інфекційному фоні Septoria tritici виділено ряд сортів. Високостійким був сорт Оберіг Миронівський.

Стійкість до Septoria tritici Rob. et Desm. проявили такі сорти: Світанок Миронівський, Легенда Миронівська, Калинова, Колос Миронівщини, Економка, Ювіляр миронівський, Миронівська сторічна, Пам’яті Ремесла та інші. Дані сорти рекомендовано для вирощування у виробництві, як сорти, які потребують мінімального хімічного захисту, та для використання в селекції нових хворобостійких сортів.

\section{Список використаних джерел}

1. Бабаяни О. В. Імунологічна характеристика рослинних ресурсів пшениці та обгрунтування генетичного захисту від збудників хвороб грибної етіології у Степу України : автореф. дис. ... доктора біол. наук : спец. 06.01.11. «Фітопатологія» / О. В. Бабаянц. - Київ, 2011. - 48 с.

2. Дослідження генетичного контролю ознаки стійкості у пшениці м'якої озимої до Septoria tritici із застосуванням різних методів оцінки [I. М. Черняєва, І. С. Лучная, С. С. Понуренко, Т. Ю. Маркова] // Генетичні ресурси рослин. - 2009. - С. 87-97.

3. Пьжикова Г. В. Септориоз зерновых культур / Г. В. Пыжикова, Л. Г. Сасенко // Защита растений. - 1987. - №3. - С. 15-16. 
4. Марютін Ф. М. Септоріоз пшениці / Ф. М. Марютін // Карантин і захист рослин. - 2011. - № 10. - С. 5-7.

5. Ретьман С. В. Септоріоз / С. В. Ретьман, С. І. Коломієць, В. М. Зібцев // Захист рослин. - 2002. - № 5. - С. 4-5.

6. Музафарова В. А. Селекційна цінність сортів пшениці м'якої озимої за стійкістю до мікозних плямистостей листя та ії успадкування : автореф. дис.... канд. с.-г. наук / В. А. Музафарова. - Харків, 2011. - 20 с.

7. Методика державного сортовипробування сільськогосподарських культур / [В. В. Волкодав, А. В. Андрущенко, А. В. Пількевич та ін.] -2000. - 100 с.

8. Септориозы зерновых культур / [Г. В. Пыжикова, А. А. Санина, Г. И. Курахтанова и др.]. - М., 1988. - 58 с.

9. Методы оценки устойчивости селекционного материала и сортов пшеницы к септориозу / [Г. В. Пыжикова, А. А. Санина, Г. И. Курахтанова и др.]. - М., 1989. - 43 с.

10. Методы селекции и оценки устойчивости пшеницы и ячменя к болезням в странах-членах СЭВ / [Л. Бабаянц, А. Мештерхази, Ф. Вехтер и др.].Прага, 1988. - 321 с.

11. Методологія оцінювання стійкості сортів пшениці проти шкідників i збудників хвороб / [С. О. Трибель, М. В. Гетьман, О. О. Стригун, та ін.]; за ред. С. О. Трибеля. - К.: Колобіг, 2010. - 392 с.

12. Методи випробування і застосування пестицидів / [С. О. Трибель, Д. Д. Сігарьова, М. П. Секун та ін.] ; за ред. проф. С. О Трибеля. - К.: Світ, 2001. - 448 c. 